\title{
Deforestation and the ideologies of the frontier expansion: the case of criticism of the Brazilian Amazon monitoring program
}

\author{
Desmatamento e as ideologias da expansão da \\ fronteira agrícola: o caso das críticas ao sistema de \\ monitoramento da floresta amazônica
}

Roberto Araújo

Ima Célia Guimarães Vieirab

${ }^{a}$ Doutor em Etnologia, Museu Emílio Goeldi, Belém, PA, Brasil E-mail: araujo.roberto808@gmail.com

${ }^{b}$ Doutora em Ecologia, Museu Paraense Emílio Goeldi, Belém, PA, Brasil E-mail:ima@museu-goeldi.com.br

doi:10.18472/SustDeb.v10n3.2019.27258

Received: 23/09/2019

Accepted: 25/11/2019

ARTICLE- VARIA

\begin{abstract}
In this article, we present some facts to contextualize the recent attacks against the Brazilian Amazon Monitoring Project carried out by the Brazilian government on the question of deforestation rates. We argue that these attacks represent a symptom of fundamental aspects of the case that need a sociological analysis of the ideologies that justify the reproduction of inequalities in the expansion of the frontier, as well as the influence that the beneficiaries of this process have acquired within the national policies for the Amazon region.
\end{abstract}

Keywords: Deforestation. Amazon Region. Amazonian Frontier. Geopolitics

\section{RESUMO}

Neste artigo, apresentamos alguns elementos que permitem contextualizar os recentes ataques ao Programa de Monitoramento do Desmatamento da Floresta Amazônica Brasileira por Satélite efetuados pelo governo brasileiro, sobre as taxas de desmatamento da Amazônia. Argumentamos que esses ataques representam um sintoma de aspectos fundamentais para uma análise sociológica das ideologias que justificam a reprodução de desigualdades na expansão da fronteira agrícola, bem como da influência que os beneficiários deste processo lograram adquirir no seio das políticas nacionais para a Amazônia.

Palavras-Chave: Desmatamento. Amazônia. Fronteira Amazônica. Geopolítica 


\section{INTRODUCTION}

The Amazon is considered one of the most important frontiers of natural capital and its occupation occurs according to a society-nature relationship paradigm in which economic growth is seen as linear and infinite, and based on the continuous incorporation of land and resources (Becker, 2005). There are different geopolitical projects operating in the region, which are responsible for the agrarian and environmental conflicts, against the background of deforestation of the richest rainforest in the world.

The concept of "Frontier" is used here not only in reference to the expansion of agricultural activities over the natural environment, but also to the characterization of social and political dynamics and processes related to this expansion. It therefore refers to an important discussion in Brazilian and international geography and sociology (cf. Martins 1975; Velho 1979).

From this perspective, deforestation is a complex problem whose characteristics vary according to the dynamics of the land market, access to consumer markets and the degree of occupation of the agricultural frontier (Pacheco, 2012).

In recent decades, a considerable and successful public policy effort has been made to reduce deforestation in the Brazilian Amazon. However, since 2012, deforestation rates have been increasing again, partly due to failures in command and control actions.

From August 2018 to July 2019 Legal Amazon deforestation was estimated at 9,762 km², which shows an increase of almost $30 \%$ over the previous period. This sudden and exponential increase is not the result of chance. Indeed, deforestation of the Amazon rainforest is nowadays explicitly encouraged by the government, as well as the devaluation of science, based on unfounded criticism of research institutions, the dismantling of environmental agencies responsible for controlling deforestation and burning. This is the symptom of an unprecedented institutional crisis. Instead of continuing policies based on constitutional normality, we have the subordination of government initiatives on the Amazon to the interests of the beneficiaries of illegal deforestation. This becomes justifiable through ideologies that deny the existence of social and environmental problems, replacing the discussion of real issues with persecutory discourse.

In this paper, we contextualize the recent attacks on the Brazilian Amazonian Satellite Forest Deforestation Monitoring Program (PRODES) by the Brazilian government, arguing that these attacks are associated with ideologies that justify the reproduction of inequalities in the expansion of the agricultural frontier, and that their resurgence is a symptom of the influence of the large owners' ("ruralists") lobbies on public policies for the Amazon. We also intend to put into perspective other phenomena associated with deforestation, such as land grabbing, to reaffirm the importance of monitoring deforestation, and to secure the territories of regional populations.

\section{OCCUPATION AND DEFORESTATION IN BRAZILIAN AMAZON}

For a long time, the occupation of the Brazilian Amazon was limited to the coastal region and the riverside strips of the main navigable rivers, as during the cycles of exploitation of the so-called "sertão drugs" in the colonial period. In the nineteenth century, the collection of rubber had caused the onslaught of the expanding fronts of national society to the high headwaters of rivers, entering uncharted territories and border areas, with new impacts on indigenous populations.

Despite this, as well as the intensification of wartime demographic expansion fronts (rubber soldiers), these extractive-based production systems had little impact on forest cover and land use. From the 1970s, however, the occupation of the Amazon became a national priority and the federal government began to make possible and subsidize the occupation of land for new activities, such as agricultural 
colonization and, above all, livestock. The new waves of demographic expansion, induced by propaganda and government credit support, have transformed the use of land in the Amazon. With increasing logging operations, gold mining and, above all, extensive livestock raising, conflicts over territorial resources have intensified and a massive removal of vegetation cover has begun.

In 1988, when the first Amazon rainforest monitoring system was launched in Brazil - the PRODES Amazônia (Brazilian Satellite Rainforest Deforestation Monitoring Program), about 90\% of the Atlantic Forest, 50\% of the Cerrado, $23 \%$ of the Caatinga and $8 \%$ of the Amazon had already been totally destroyed.

Deforestation in the Legal Amazon between 1988 and 1990 was associated with the history of occupation of the Amazon, with the opening of federal roads and the implementation of colonization, hydroelectric and mining projects. and occurred especiallyin the so-called "arc of deforestation", encompassing mainly the states of Pará, Maranhão, Mato Grosso and Rondônia (Becker, 2005). Beginning in 2000 (Figure 1 ), new hotspots of deforestation emerged, localized and led by an endogenous regional economic dynamic characterized by a greater diversity of local actors with private capital (Becker, 2005).

PRODES, designed and implemented by the hands of selfless scientists at the National Institute for Space Research-INPE, was a pioneering initiative. Deforestation in the Amazon has been monitored by INPE since 1970, when the rate of destruction intensified, especially in the Amazon and Cerrado. With the creation of PRODES, whose data has an annual base and a historical series of about 30 years, the monitoring began to be done systematically, providing for the first time in the history of the planet a set of rigorously measured data about the use of forest resources. identifying and quantifying their consequences for climate change (carbon emissions), biodiversity and the maintenance of aquifers.

Moreover, the PRODES data made it possible to unambiguously associate certain economic activities with deforestation. The best example is extensive cattle ranching which, highly concentrated in land, accounted for over $60 \%$ of deforestation (Almeida et al., 2016). This was also confirmed by IBGE data. In a study of a universe of nearly 444,000 rural establishments registered in 1995 for the Amazon, large livestock, which housed only $11 \%$ of the people employed in the rural economy, took over $60 \%$ of the land and had been by far the largest beneficiary. of credit and technical assistance among all rural economic trajectories considered in the study of Costa (2012).

The creation of the National System of Conservation Units (SNUC) in 2000 represented an advance of perspectives by establishing a robust mechanism to ensure the creation, implementation and management of Conservation Units (UCs) in Brazil. From then on, the implementation by the federal government of a territorial management program began to guide the Amazonian productive systems towards more sustainable practices, while valuing those rural trajectories that had managed the forests without destroying them.

This was the case of the vast riverside populations, inhabitants of Sustainable Use Conservation Units, which have enormous relevance in food production and whose role in the regional economy, however, had always been minimized, if not entirely denied, by those who believe that only the large-scale business activity generates noteworthy value. This was also the case with indigenous populations, whose importance in the centuries-old management of forests, based on a thorough knowledge of plant and animal species, had been demonstrated since the 1980s (Posey, 1985).

The Protected Areas (Conservation Units plus Indigenous Lands, whose number of approvals had accelerated in the period 1995-20021) would quickly demonstrate their effectiveness in combating deforestation, whose amount was about ten to twenty times smaller inside Conservation Units and Indigenous Lands than in contiguous areas outside them (Ferreira et al., 2005).

Given the alarming level of the deforestation rate of over $20,000 \mathrm{~km} 2$ in 2004, the Brazilian government created the Deforestation Prevention and Control Action Plan in the Brazilian Amazon-the PPCDAM. The creation of this plan took into account the complexity of the origins of deforestation and its environmental, social and economic consequences. 
Deforestation in the Amazon has always been associated with problems such as violent land conflicts, leading to hundreds of murders of indigenous and peasants each year, land grabbing, and use of labor under slave-like conditions (Araújo et al .2019). For this reason, it was dealt with at the highest level of public policy of the federal government, being coordinated by the Chief of Staff of the Presidency of the Republic (Casa Civil), with the participation of eleven ministries.

After 2006, there was a sharp decline in deforestation rates that continues until 2011 (Figure 1), reaching $6,238 \mathrm{~km}^{2}$, which is the lowest rate recorded in the historical series. The command and control actions of PPCDAM, articulated with transversal actions of various institutions of the Brazilian state, partly explain the decline in deforestation rates. The grain and meat market as well as internal and international pressures also contributed to this reduction.

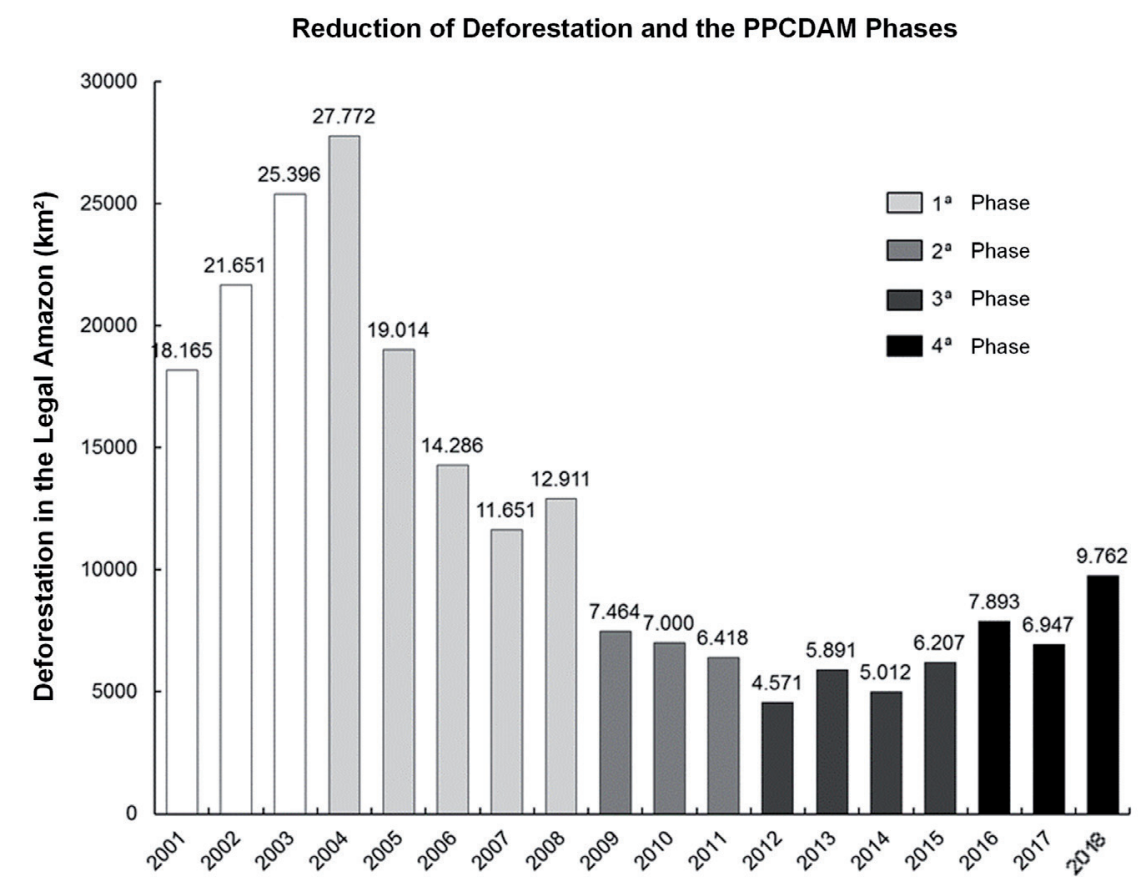

Figure 1 | Amazon deforestation in the period 2001-2018 and the PPCDAM phases.

Source: PRODES-INPE (2019).

The PPCDAM's actions accounted for about $52 \%$ of the decline in this rate and prevented the emission of 270 to 621 billion tons of carbon dioxide between 2004 and 2010 (Assunção et al., 2012). Each enforcement action prevented deforestation from 4 to 9.9 ha (Borner et al., 2015) and this was considered the single largest contribution by one country to combating global warming.

The success of the PPCDAM was due to innovative forms of satellite monitoring, which in addition to PRODES, relied on the DETER--Real-Time Deforestation Detection system for the definition of command and control actions (Mello \& Artaxo, 2017). This system allows to define and modify the actions of the inspection dynamics quickly. It was implemented under PPCDAM to support IBAMA's oversight and its data are released monthly and compared to the same period in previous years. Both systems are open and subject to public verification and have distinct functions.

To understand satellite monitoring systems it is necessary to understand the main disturbance processes underway in the Amazon rainforest. There are two distinct processes: logging and burning (or deforestation) and forest degradation. In deforestation, vegetation is cut at the beginning of the dry season and burned at the end of the dry season. In the process of forest degradation, selective logging is performed, followed by burning, new logging, and so on, in an increasing degradation of forest cover. 
Regarding what is detected in the different systems, depending on their objectives, it is important to highlight that PRODES only identifies and accounts for areas that have been cleared, that is, the final stage of the deforestation process. In DETER, every change in forest cover verified in the period under analysis is indicated as an Alert area and can be monitored; so DETER seeks to identify the initial and intermediate stages of the deforestation process (INPE, 2019). INPE'S PRODES and DETER monitoring systems detect these disturbances and monitor them as follows:

- PRODES: calculation of annual deforestation (clear cut deforestation) rates based on images from USGS Landsat 8 satellite (US), INPE / CRESDA CBERS-4 (Brazil / China), and ISRO ResourceSat 2 (India), covering the entire length of the Amazon annually.

- DETER: monitoring deforestation polygons based on new images collected every 4 days by the WFI sensor aboard the CBERS-4 satellite with a spatial resolution of 64 meters. The adopted procedure allows the identification of both clearcut and forest degradation stages, as illustrated in figure 2 (INPE, 2019).

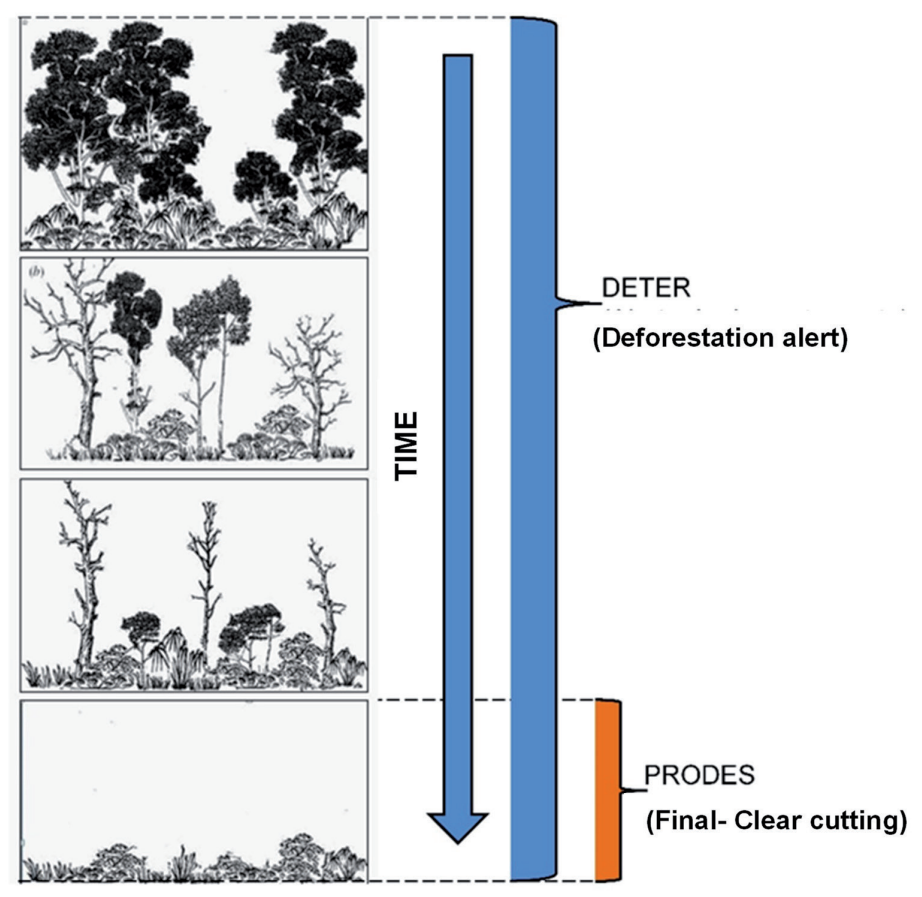

Figure 2 | Comparison of PRODES and DETER systems regarding detection time and disturbance processes in the Amazon rainforest.

Source: INPE (2019).

\section{GEOPOLITICS AND MEASURES TO STOP DEFORESTATION - GOVERNMENT CRITICS}

President Jair Bolsonaro's criticism of this internationally recognized system, as well as his condemnation of physicist Ricardo O. Galvão, INPE director until July 2019, accused of "lying" about deforestation data and "serving some NGO" when disclosing information that puts Brazil "in a complicated situation", tried to weaken the legitimacy and the value for the Brazilian society of the Institute. These were not the first that INPE had to endure. First of all, it is worth noting that it is the tragedy of deforestation itself and the associated cohort of violence against local populations that puts Brazil in a "complicated situation", not its monthly (DETER) or annual (PRODES) data publication.

In 2008, the government of Mato Grosso, Blairo Maggi - also one of the soy production giants - had challenged INPE's deforestation data by confronting them with its own monitoring system - the SAD (deforestation alert system), developed - in this case - by a non-governmental organization, the Amazon 
Institute of Man and Environment - IMAZON, working for the government of Mato Grosso. INPE then produced a report based on field data checking procedures demonstrating that its conclusions were accurate and in agreement with the $f$ reality verified in loco. A copy of the report was handed to a representative of the government of Mato Grosso during the seminar "Deforestation in the Amazon: A Necessary Dialogue. Is it possible?", organized by the authors and other colleagues, in Belém-PA at the Museu Paraense Emilio Goeldi, on May 6 and 7, 2008.

The major interest of this seminar was to bring together scientists, public managers, and representatives of NGOs and the private sector to discuss deforestation. Some points raised, such as the need to restore pastures and intensify livestock to prevent their expansion to new forest areas, as well as the development of permanent crops - such as cocoa, especially for family farming - then seemed to gather some consensus among market stakeholders.

Initiatives associating these stakeholders with environmental protection have been ongoing since 2006, such as the soy moratorium, a pact in which associations such as the Brazilian Vegetable Oil Industry Association (ABIOVE) and the Brazilian Cereal Exporters Association (ANEC) pledged to not receive membership production planted in ad hoc deforested areas for large-scale agriculture. This was followed by the "cattle moratorium". These product certification processes, with the participation of the private sector, also depended on the implementation of a Rural Environmental Registry (CAR), provided by the 2012 Forest Code, which would allow the producers' compliance to be verified at the scale of the municipalities and properties, in according to environmental legislation and its provisions, such as the maintenance of the Legal Reserve (area of native vegetation maintained on the rural property) and the APP's (Permanent Protection Areas, necessary for the preservation of aquifers, the reduction of erosion, etc.).

Although imperfect and the object of widespread criticism (Schmink et al., 2017) across the social fields, from large-scale farmers to environmentalists and social movements, these and other institutional arrangements represented attempts to establish the rules and institutional support (the regras do jogo--"rules of the game") for a better use of the Amazonian natural resources, combining economic valorization, social protection of populations and mitigation of environmental impacts, in accordance with the laws and the Constitution of the country. However, it has also generated profound dissatisfaction and resistance, especially from local elites, who have benefited from the processes of illicit and violent appropriation of public lands, which have the political control of the municipalities, and the powerful support on the Brazil's bancada ruralista, the agribusiness lobby in the National Congress.

The FAEPA (Pará Federation of Agriculture and Livestock) representative at the Goeldi Museum Seminar in 2008 synthesized the vision of the rural elites, stating that the protected areas caused a "stagnation of the economy of the Amazon"2. He said he did not agree with the proposal for a new (sustainable) economic model for the region and believed that there was a fundamental conflict between environmental issues and development. His talk outlined a conspiracy theory that NGOs, environmental activists and indigenous people would be the agents of something similar to the infamous protocol of the sages of Zion, a "Global Governance", which would include "foreign government agencies from powerful countries (China), France, Germany ...)", while" sustainable development, Agenda 21, climate reports and reserves (protected areas) would be nothing more than disguises, masks to cover the truth: economic interest and market dominance "(sic).

Among the proposals presented by FAEPA aiming at a conciliation to stop the pressures of the national and international environmental apparatus, was the use of $100 \%$ of the already deforested areas, and the extinction of the legal reserves. We will come back in conclusion to this point, whose current relevance was renewed with the discussion of a bill authored by Senators Flávio Bolsonaro and Marcio Bittar. 


\section{CONSTITUTIONAL REGIME AND MORAL OF RESENTMENT}

There is, however, a caveat. There is a clear reversal of the logic underlying the expansion of the agricultural frontier in the FAEPA speech. For in fact, instead of being a "global governance market domain", protected areas stop deforestation precisely by establishing rules for the appropriation and use of natural resources. They thus interrupt the process of savage privatization of vast forested areas through the use of fraud and violence against resident populations whose tenure or property rights are undefined or poorly protected.

The owners of the lands, after "clearing" them (of forest and people), expect to sell part of them to other economic agents, as investments in infrastructure are emerging. This speculative activity is at the same time behind much of the region's deforestation and the creation of a land market (Costa, 2012), benefiting a group of individuals who see themselves as "pioneers" (Boechat, 2014).

Although they share the epithet of "pioneers" with investors from outside the Amazon to multiply their assets in the region, several "pioneers" are rarely entrepreneurs in the modern sense of a professional exercising a business. These are often agents brought to the region by economic enterprises, hommes a tout faire of logging companies, large gold miners, etc., whose main characteristic beyond canine devotion to their patrons is the search for accumulation by any means available, rejecting any attempts to regulate their impulses.

We are not here, of course, to make moral judgments about the behavior of isolated individuals. It is about bringing to light certain 'communities of dispositions and interests' (Bourdieu, 2000: 99) that function as habitus in Bourdieu's sense, and allow us to characterize observable systems of practice as structures determined by history. As the frontier consolidates, the "pioneers" become the political representatives of newly formed municipalities, with full control over the executive, the legislature, public security, and so on, in place (Fernandes, 1999). Structurally incapable of recognizing anything other than their irrepressible desire for social promotion, they can only destroy the legitimacy of the institutions they should represent, and try to relegate to invisibility or insignificance the other actors who dispute with them the territory (indigenous and quilombolo populations and social movements).

Violence against these minorities, sometimes translated into murders of leaders as annually accounted by the Pastoral Land Commission (CPT, 2019), thus finds abundant ideological justification. We could mention these irregular, low-circulation editions, books and magazines produced by authors expressing the point of view of the rural elites. For example, the issue of the magazine "Hoje" no 3, year II, found in Altamira and which currently seems to have disappeared without leaving any trace, already announced in 2005 that "NGOs, the Catholic Church and PT want to transform the Amazon into the planet's guinea pig", and that "the environment and the Indians are used as subterfuge" for vested interests. Published in Oriximiná, the book Konduriland, whose author is chairman of a local OSCIP, stated - regarding the demarcation of quilombola areas presented as "the quilombos farce":

Without ghosts (sic), tanks or submachine guns a large landholding on the order of 371,000 hectares is being formed, corresponding to about $3.4 \%$ of the territory of the municipality of Oriximiná. The mechanism may lie in a legal breach left by the constituents as the lights go out, now diligently manipulated by alien groups [who strictly follow the booklet of the Pro-Indian Commission of São Paulo] to the detriment of local interests, diminished by a good deal of omission of our rulers ${ }^{3}$.

To accuse environmentalists and NGOs of being agents of a "market dominance" is obviously contradictory to the fact that the authors of this discourse themselves are objective allies, facilitators, when not direct partners of the appropriation of the Amazonian natural resources by the capital (national or international). But coherence and truth are not relevant to the aims of this discourse, whose function is otherwise: to generate a consensus contrary to those perceived as 'enemies' and thus build their own legitimacy. 
When the president states that the director of INPE "may be at the service of some NGO", he takes up a narrative similar to that of FAEPA to discredit not only the scientific institution, but also the entire apparatus established over the last decades, to frame the negotiations on deforestation and resource use in the Northern region, including the relevance of the role of protected areas.

It would be a mistake to minimize the power of conviction of this discourse, or to disregard it for the lack of factual basis. For it is not based on facts, but on the construction of an imaginary enemy communism, ethnic minorities, homosexuals, climate change, no matter what - that triggers reactions within Brazilian society. "I say they lie, so I tell the truth": This syllogism of lies has considerable support in a system of power that seeks deregulation through the weakening of the constitutional regime. It takes deep root in a moral of resentment that shapes and divides the political field, invalidating any rational debate.

As Nietzsche $e^{4}$ said:

"If we imagine 'the enemy' as a man of resentment conceives him-and right here we have his action, his creation: he has conceptualized 'the evil enemy', 'the evil one', as a fundamental idea-and from that he now thinks his way to an opposite image and counterpart, a 'good man'-himself!" (NIETZSCHE, F., p. 55).

It turns out then that the summary dismissal of the director of INPE is simply a consequence of the systematic attempt to subject reality to a manufactured truth, turning institutions into a meaningless idea, by means of a strategy in which even the scandalous truculence of public pronouncements has its raison d'être, for it paves the way for previously repressed actions: attacks on public enforcement agents, murder of indigenous people, escalation of extermination by police groups and militias, etc ${ }^{5}$.

Recent examples abound: so during the attempt of land grabbing in an indigenous territory near $\mathrm{S}$. Félix do Xingu area (Xicrin, Trincheira Bacajá) in the second half of June 2019, Bekara Xicrin, leader of one expedition against the land-grabbers, said he heard from one of them: "The land is free, Bolsonaro released it (for us), that's why we came. We want to work, we want to help indigenous people"6.

On August 5, a newspaper from Novo Progresso, a municipality in the BR-163 area, announced the promise of a "fire day" in which rural farmers in the city pledged to increase fire outbreaks on August 10 " to draw the attention of the authorities that in the region the advance of production happens without government support, [and] show the President that we want to work and the only way is to deforest and to shape and clean our pastures is by the use of fire7". Under the complacent scrutiny of the executive, there was in fact an extraordinary increase of fire outbreaks in several municipalities of western Pará.

The attacks against the truth are also seeking legislative support. The proposal to repeal the Legal Reserve areas in the Forest Code returned to discussion with the bill 2362/2019 of Senators Flávio Bolsonaro (PSL / RJ) and Marcio Bittar (MDB / AC), until recently pending in the Federal Senate, which justifies it to "enable the economic exploitation of these areas". However, the Legal Reserve does not hinder Brazilian agricultural production and should not be considered "unproductive land" because its sustainable use has always been ensured by law. Legislation in defense of the expansion of agricultural frontiers and the interests of large landowners uses the "constitutional guarantee of protection of private property" argument, which is actually the subterfuge to increase the land market reserve for companies, ruralists (including politicians) and other agents.

Faced with national and international criticism of the increasing rate of forest destruction, however, PL 2362 has been - at least temporarily - removed from the agenda. But this is far from a breakthrough. One of the Project's authors comments on the subject: 
“(...) Ecological bureaucrats continue to propagate misinformation that inspires the unsuspecting to defame those who most preserve native vegetation: agricultural producers. NGOs and international bodies should reward them for preservation. (...) Unfortunately, a certain radical and fundamentalist environmentalism feeds actions interested in impeding our development (...) to allow the expansion of agriculture in other large producing countries (...). The withdrawal of the project was a vote of confidence to the Federal Government. There was an objective proposal to create an interministerial group, led by the President of the Republic and coordinated by the Minister of the Environment, with the objective of presenting (...) projects and programs to be executed in favor of the Amazon. I am part of the group with pride and a great desire to work. (...) It is known that the laws need to be relaxed to allow production in conservation areas, indigenous lands and extractive reserves" ${ }^{\prime \prime}$.

The formation of this interministerial group apparently has the vocation of replacing the PPCDAM, and would already be born with the stated intention of contradicting the existing rules to allow the unbridled mechanisms that preside over the formation of the Amazonian land market.

\section{WHO IS INTERESTED IN NOT MONITORING DEFORESTATION?}

A recent study (ITPS, 2019) recognizes the Amazon as the largest mineral province and main biogenetic reserve on the planet, and one of the most desired territories by Capital. As most privately occupied land is state-owned, uncontrolled by land tenure, environmental and deforestation problems in the Amazon tend to get worse until the land problem is resolved. In the state of Pará, champion of deforestation, $39 \%$ of the territory needs land regularization of possession and most of it is federal land (Bennatti \& Fischer, 2017). The study states that by signaling the loosening of environmental laws, and giving priority to its infrastructure and financing projects, by the government of Jair Bolsonaro, the region is likely to become even more a land dispute hub and supplier of material commodities increasingly dependent on agribusiness and mining (ITPS 2019).

Given this scenario, knowing where deforestation happens is essential to efforts to prevent or slow its expansion in the amazon frontier area. However, the satellite technology behind forest monitoring platforms is unable to identify the underlying vectors of loss of vegetation cover. Inpe's data show us the magnitude and location of the problem, but understanding the interests and actors behind deforestation requires in-depth study.

For at least ten years, scientists have been showing that there is a positive correlation between the growth of global commodity markets and the conversion of rainforest to agricultural use, which has replaced local demand as the main vector for deforestation (DeFries; Rosenzweig, 2010). Of course there is legal deforestation, but we have no way of knowing the figure of illegal versus legal.

It is estimated that in 2016, over $80 \%$ of deforestation in the Amazon and one third of the clearing of native vegetation in the Cerrado occurred on properties that had already cleared the legally permissible maximum area and are therefore likely to be illegal (Trase, 2018). The issue of land grabbing in the Amazon has become chronic and state-endorsed, with a favorable environment for reducing public lands and lands for traditional and indigenous populations over large areas.

The legalization of land grabbing (Figure 3 ) happens because the land agencies do not verify the existence of the area and the presence of previous residents in the municipal bodies, do not georeference the areas nor verify documents issued by the notary's offices in the region. As land registration in INCRA is selfdeclared there is no real knowledge of the extent of the problem. And the issue only gets worse, because the Rural Environmental Registry is also self-declared and totally dissociated from the land registry. 


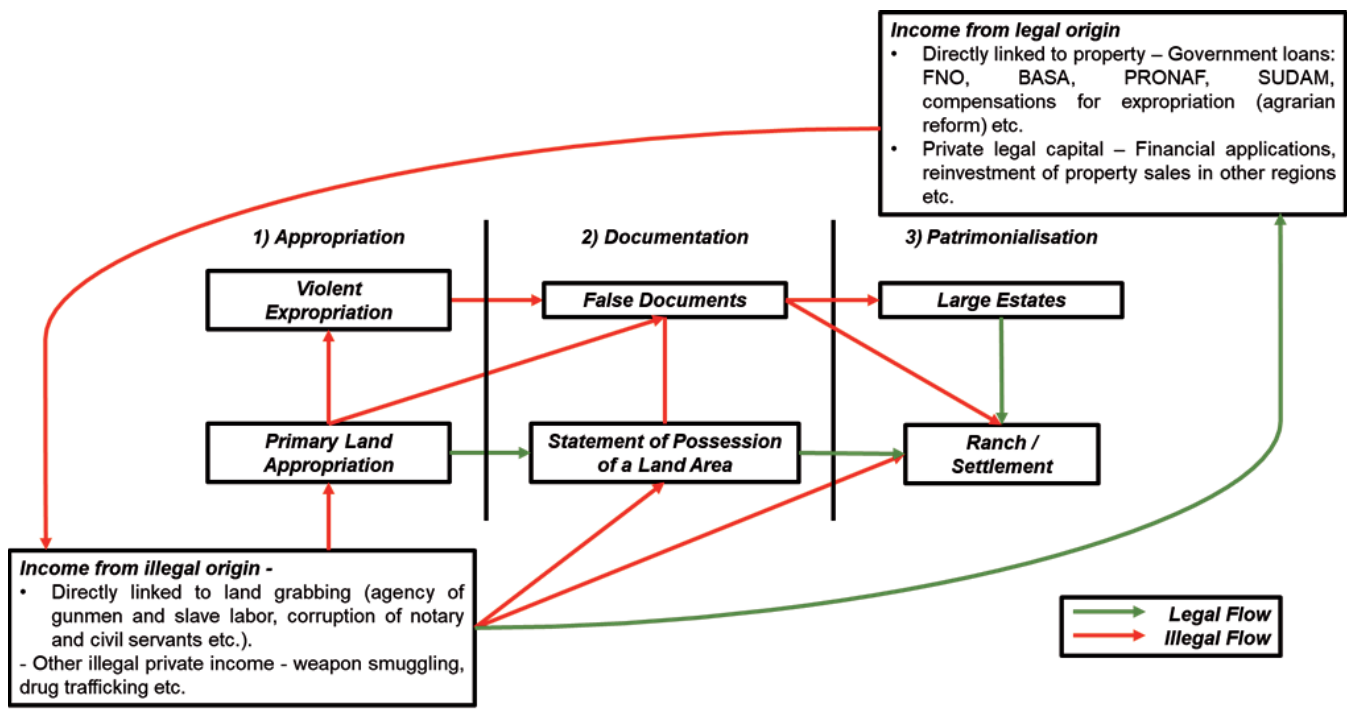

Figure 3 | Model of land grabbing in the Amazon.

Source: authors (2019).

Deforestation for land speculation (land grabbing) through the invasion of public land in 2016 was at least $24 \%$ of total deforestation (IPAM, 2017). On the other hand, the link between deforestation and land speculation (Miranda et al., 2019) suggests that land market prices in Brazil are not merely governed by expectations about rents and forest conversion costs. Expectations for future infrastructure improvements and conservation-induced land scarcity are taken into account in current land market transactions.

There is evidence that the Brazilian land market conveys information about possible conservation policy leaks and explores this conjecture using dynamic deforestation hotspot maps in both the Amazon and the Cerrado. From this perspective, it became clear that deforestation in the Amazon, which was under strong environmental monitoring and other governance measures (eg, Soy Moratorium), moved to Matopiba, a region composed of four Brazilian states, Maranhão, Tocantins, Piauí and Bahia, in a transition area between Amazonia and the Cerrado, where soybean plantations increased by $310 \%$ between 2001 and 2017. In fact, in the Cerrado, the level of legal protection was always lower than that of the Amazon and levels of institutional and technical capacity in local government agencies, including environmental enforcement, were also very low.

With the weakening of environmental inspection and environmental agencies, high rates of deforestation are expected in the Amazon region, as well as in the Brazilian Cerrado, from 2019.

\section{FINAL CONSIDERATIONS}

Deforestation in the Amazon affects more than trees. Traditional populations, especially indigenous peoples who have lived in these forests for thousands of years, and who have developed sustainable resource utilization systems, are often threatened and displaced by deforestation. For these people, as for other victims of expropriation, the tragedy is immediate; for others, the negative consequences of deforestation are less obvious. They are cumulative and their total impact is gradual and spans generations.

In such a context, maintaining INPE's environmental monitoring systems with transparency and autonomy is indispensable to support responsible decisions on land use management and the development of sustainable agricultural production. In addition, the systems ensure compliance with the New Forest Code and creates confidence in the country in international trade agreements.

Deforestation control systems thus represent an essential mechanism for true monitoring of the Amazon biome, enabling the conservation of its biological and social diversity, and guaranteeing the 
territories of traditional populations. It is therefore essential that the collective character and social function of public policies, and the autonomy of institutions, be respected, so as not to give in to the mere interests of particular groups. Without this, illegal deforestation will continue to thrive, coupled with the predation of life and natural resources, based on the subversion of the institutional order.

In a democratic system of conducting science, it implies the exercise of social responsibility by scientists and full transparency of public data.

\section{NOTES}

1 | Cf. https://cimi.org.br/terras-indigenas/. We could mention from this period the approval, in particular, of the Indigenous Land of Alto Rio Negro, with $\mathbf{1 0 . 6}$ million hectares. The Plan for the Protection of Indigenous Lands in the Legal Amazon (PPTAL), sub-program of the Pilot Plan for the Protection of Tropical Forests (PPG-7), fully operative at this time, would make a decisive contribution to the record numbers of approvals of indigenous lands by the administration (145), in a moment of great legitimacy of the "socio-environmental model" also due to the political impacts of the United Nations Conference on the Environment and Development, also known as Eco-92, in Rio de Janeiro. (cf. Araújo \& Lena Da predação à sustentabilidade na Amazônia: a difícil metamorfose in Araújo \& Lena eds. Desenvolvimento Sustentável e Sociedades na Amazônia Belém, MPEG 2011).

2 | Cf. Final report of the seminar "Desmatamento na Amazônia: um diálogo necessário. É possível? http://www. inpe.br/noticias/arquivos/pdf/relatorio_final_desmatamento.pdf.

3 | Almeida, J. B op.cit. Oriximiná, Fundação Ferreira de Almeida s/d p. 114.

4 | NIETZSCHE, F. La généalogie de la Morale (3 ed.) Mercure de France, Paris, 1900. Pp 55.

5 | Cf Grillo, C.; Godoi, R. Simulacros : a hiper-realidade do extermínio in Le monde diplomatique Brasil, junho de 2019 ; https://g1.globo.com/pa/para/noticia/policia-federal-e-acionada-para-investigar-ameacas-a-servidoresdo-ibama.ghtml; https://www.gazetadopovo.com.br/vida-publica/encontrado-corpo-de-colaborador-do-ibamaa9nk18dfrb5th27vrn5w5edzi/;https://cimi.org.br/2018/09/relatorio-cimi-violencia-contra-os-povos-indigenasno-brasil-tem-aumento-sistemico-e-continuo/

6|https://www1.folha.uol.com.br/ambiente/2019/08/abandonados-pelo-governo-federal-indios-xikrinretomam-area-de-grileiros-no-pa.shtml;https://www.brasil247.com/brasil/indigenas-do-sudeste-do-parapodem-ser-atacados-por-grileiros-alerta-mpf

7 | http://www.folhadoprogresso.com.br/dia-do-fogo-produtores-planejam-data-para-queimada-na-regiao/.

8| Marcio Bittar https://www.tercalivre.com.br/marcio-bittar-fala-sobre-o-fim-da-reserva-legal/.

\section{REFERENCES}

ALMEIDA, C. A. et al. High spatial resolution land use and land cover mapping of the Brazilian Legal Amazon in 2008 using Landsat-5/TM and MODIS data. Acta Amazonica, v. 46, n. 3, 2016.

ANUÁRIO TRASE. Sustentabilidade das cadeias de produção: risco de desmatamento na exportação de soja brasileira. Transparência para Economias Sustentáveis. Instituto Ambiental de Estocolmo e Global Canopy. 2018.

ARAÚJO, R.; LÉNA, P. Da predação à sustentabilidade: a difícil metamorfose. In: (ed.). Desenvolvimento sustentável e sociedades na Amazônia. Belém: Museu Paraense Emilio Goeldi, p. 4-39, 2010.

ARAÚJO, R. et al. Territórios e alianças políticas do pós-ambientalismo. Estudos Avançados, v. 33, p. 67-90, 2019.

ASSUNÇÃO, J.; CLARISSA, C.; GANDOUR, R. R. Deforestation slowdown in the Legal Amazon: prices or policies? Climate Policy Initiative, San Francisco, California, USA. [on-line] URL: Disponível em: $<$ http://climatepolicyinitiative. org/wp-content/uploads/2012/03/Deforestation-Prices-or-Policies-Working-Paper.pdf>. 2012. 
BECKER, B. Geopolítica da Amazônia. Estudos Avançados, v. 19, n. 53, 71-86. 2005.

BENATTI, J. H.; FISCHER, L. R. da C. New trends in land tenure and environmental regularisation laws in the Brazilian Amazon. Regional Environmental Change, v. 18, p. 11-19, 2018.

BOECHAT, C. A. O conceito de "pioneiro" na Geografia, na contraposição de estudos sobre expansão cafeeira e a citrícola. Confins Revista Franco-brasileira de Geografia, n. 21. Disponível em: <https://journals.openedition. org/confins/9667?lang=pt>. 2014.

BORNER, J.; MARINHO, E.; WUNDER, S. Mixing carrots and sticks to conserve forests in the Brazilian Amazon: a spatial probabilistic modeling approach. PloS one, v. 10, n. 2, p. e0116846, jan. 2015.

BOURDIEU, P. Le Sens Pratique. Paris, Ed. De Minuit p. 94-95. 1980.

COMISSÃO PASTORAL DA TERRA. Conflitos no campo Brasil 2018. Centro de Documentação Tomás Balduíno, Goiânia, 247p., 2019.

COSTA, F. de A. Mercado de terras e trajetórias tecnológicas na Amazônia. Economia e Sociedade, v. 21, n. 2 , 2012.

DEFRIES, R.; ROSENZWEIG, C. Toward a whole-landscape approach for sustainable land use in the tropics. Proc. Natl. Acad. Sci., 107, 19627-19632. 2010.

FERNANDES, M. Donos de Terras: trajetórias da união democrática ruralista. Belém, Ed. NAEA, 1999.

FERREIRA, L. V.; VENTICINQUE, E.; ALMEIDA, S. O desmatamento na Amazônia e a importância das áreas protegidas. Estudos Avançados, v. 19, n. 53, p. 157-166. 2005.

INSTITUTO DE PESQUISA AMBIENTAL DA AMAZÔNIA. Desmatamento zero na Amazônia: como e porque chegar lá. Sumário Executivo. 2017.

INSTITUTO NACIONAL DE PESQUISAS ESPACIAIS. Relatório Técnico INPE: monitoramento da floresta amazônica brasileira por satélites. Os Sistemas de Monitoramento Deter e PRODES, Julho de 2019.

INSTITUTO TRICONTINENTAL DE PESQUISA SOCIAL. Amazônia Brasileira: a pobreza do homem como resultado da riqueza da terra. Dossiê n. 14, 2019.

MARTINS, J. S. Frente pioneira: contribuição para uma caracterização sociológica. In: Capitalismo e tradicionalismo no Brasil: estudos sobre as contradições da sociedade agrária no Brasil. São Paulo: Ed. Pioneira, cap. 3, p. 43-50. 1975.

MELLO, N. G. R.; ARTAXO, P. Evolução do Plano de Ação para Prevenção e Controle do Desmatamento na Amazônia Legal. Revista do Instituto de Estudos Brasileiros, Brasil, n. 66, p. 108-129, 2017.

MIRANDA, J. et al. Land speculation and conservation policy leakage in Brazil. Environmental Research Letters, v. 14, 2019.

PACHECO, P. Actor and frontier types in the Brazilian Amazon: assessing interactions and outcomes associated with frontier expansion. Geoforum, v. 43, n. 4, p. 864-874, 2012.

POSEY, D. A. Indigenous management of tropical forest ecosystems: the case of the Kayapó indians of the Brazilian Amazon in Agroforestry systems. v. 3, p. 139-158, 1985.

SCHMINK, M. et al. From contested to 'green' frontiers in the Amazon? A long-term analysis of São Félix do Xingu, Brazil. The Journal of Peasant Studies, v. 46, n. 2, p. 377-399, 2017.

VELHO, O. Capitalismo autoritário e campesinato. São Paulo, Ed. Diffel. 1979. 